\title{
Eksistensi budaya erturtur atau tradisi santun bertegur sapa pada komunitas persadaran Batak Karo Kota Cimahi
}

\author{
Lili Halimah ${ }^{1}$, Heni Heryani ${ }^{1}$, Mada Kencana Barus ${ }^{1}$ \\ 1,2,3 Prodi PPKn STKIP Pasundan, Kota Cimahi, Jawa Barat, Indonesia
}

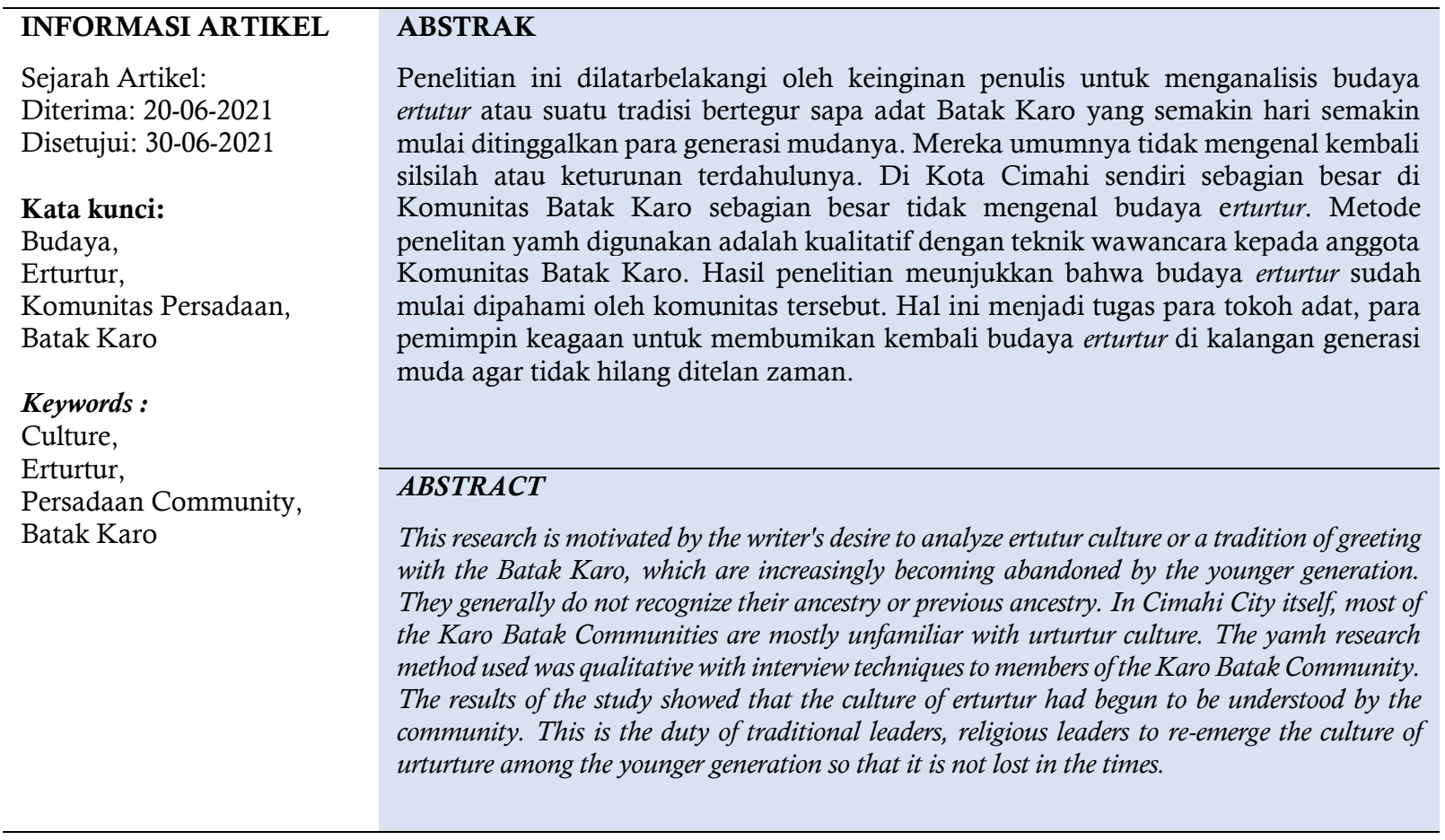

\section{Pendahuluan}

Manusia merupakan makhluk sosial yang hidup dan berkelompok, dimana setiap individu saling membutuhkan satu dengan yang lainnya, karena itu dalam kehidupan sehari-hari tidak luput dari interaksi maupun komunikasi. Komunikasi adalah proses penyampaian pesan dari komunikator kepada komunikan atau audiens baik itu dalam bentuk simbol/lambang dengan harapan bisa membawa atau memahamkan pesan itu kepada peserta didik (siswa) jika di kelas atau pada masyarakat serta berusaha mengubah sikap dan tingkah laku (Inah, 2015). Tidak ada satu manusia pun yang dapat hidup tanpa adanya peran dari manusia lainnya, maka dari itu manusia juga membutuhkan aktivitas sosial antar sesama, dimana hubungan sosial yang terjalin bisa terjadi pada sesama manusia yang sudah lama saling mengenal maupun baru pertama kali bertemu dalam kehidupan sehari-hari (Hantono \& Permatasari, 2018).

Sifat hakiki manusia sebagai makhluk sosial dapat dipahami bahwa kehidupan manusia harus berkomunikasi dengan sesamanya sebagai saran dalam menata diri, dengan kata lain, dalam menjalani kehidupannya manusia membutuhkan lingkungannya untuk berinteraksi dan berkomunikasi dengan berbagai upaya yang dilakukan agar dapat diterima di lingkungan sosialnya (Kamaruzzaman, 2016). Dalam menjalin sebuah interaksi tersebut, sikap saling memahami merupakan modal yang utama dalam membangun komunikasi tersebut. Hal ini akan dipengaruhi oleh bahasa, latar belakang budaya maupun tujuan, sehingga terbangun kontak sosial dalam interaksi 
dengan orang yang ada di sekitar kita. Untuk membangun komunikasi dibutuhkan kemampuan untuk mampu berinteraksi. Selain itu dibutuhkan juga pengakuan antara satu dengan yang lain yang menjadi fondasi penting dalam membina komunikasi, sehingga terwujud perkataan yang benar, perbuatan yang baik, dan mencapai tujuan yang dimaksud dalam berkomunikasi (Perangin-angin, 2015).

Manusia telah berkomunikasi selama puluhan ribu tahun. Sebagian besar waktu jaga manusia digunakan untuk berkomunikasi. Meskipun demikian, ketika manusia dilahirkan tidak dengan sendirinya dibekali dengan kemampuan untuk berkomunikasi efektif. Kemampuan seperti itu bukan bawaan melainkan dipelajari. Peristiwa komunikasi dua orang mencakup hampir semua komunikasi informal dan basa-basi, percakapan sehari-hari yang kita lakukan sejak saat kita bangun pagi sampai kembali ke tempat tidur. Komunikasi diadik juga merupakan komunikasi yang mencakup hubungan antar manusia yang paling erat, misalnya komunikasi antara dua orang yang saling menyayangi (Tubbs \& Moss, 2005)

Budaya terdiri dari gagasan dan "hal-hal" yang diwariskan dari satu generasi ke generasi berikutnya dalam masyarakat - pengetahuan, kepercayaan, nilai, aturan atau hukum, bahasa, adat istiadat, simbol, dan produk material (seperti makanan, rumah, dan transportasi) itu membantu memenuhi kebutuhan manusia. Budaya memberikan pedoman untuk hidup. Mempelajari budaya kita membuat dunia sosial kita dapat dipahami kerangka kerja, menyediakan kita alat yang bisa kita gunakan untuk membantu kita membangun makna dunia kita.

Menjelaskan bahwa bagaimana pentingnya peran komunikasi antar setiap manusia supaya terjalin aktivitas yang dapat memahami peranan dan maksud dari setiap individu sosial. Tatanan masyarakat sipil terjalin dari komunikasi dan pertukaran yang sedang berlangsung antara orang-orang melalui proses interpersonal, informal, dan budaya serta melalui lembaga formal dan saluran resmi (PANOS, 2013). Komunikasi menyediakan informasi yang diperlukan individu dan kelompok untuk mengambil keputusan dengan mentransmisikan daya yang diperlukan untuk mengidentifikasi dan mengevaluasi pilihan. Dengan demikian komunikasi membantu memfasilitasi pengambil keputusan (Saini, 2019)

Indonesia memiliki beragam etnis dan setiap etnis ini memiliki budaya yang berbeda-beda. Suku Batak adalah penduduk asli di propinsi Sumatra Utara, secara khusus terdiri dari enam sub suku, yaitu Karo, Simalungun, Pakpak, Toba, Angkola, dan Mandailing. Pada tahun 1961 orang Karo mendiami suatu wilayah paling utara di Sumatra Utara yang wilayahnya meliputi daerah induk dataran tinggi Karo, Langkat Hulu, Deli Hulu, Serdang Hulu, dan sebagian kabupaten Dairi (Sugiyarto, 2017). Tatanan adat budaya masyarakat suku Batak Karo sejak zaman nenek moyang telah memiliki banyak budaya yang dipertahankan dan dilakukan serta dipelajari sampai sekarang ini. Suku Batak Karo memiliki tradisi yang dilakukan oleh setiap orang Batak ketika pertama kali bertemu, dimana semua suku Batak juga melakukan hal yang sama, ini disebabkan karena suku Batak sangat menjunjung tinggi kekeluargaan. Agar mengetahui kekeluargaan tersebut dengan jelas, suku Batak Karo memiliki tradisi dalam memulai pembicaraan, tradisi tersebut disebut ertutur (Sibero \& Sibero, 2017).

Ertutur merupakan salah satu ciri masyarakat Karo dalam hal berkenalan yang biasanya diawali dengan menanyakan marga dan bere-bere seseorang. Selain itu, dapat pula dikaitkan dengan keluarga yang dikenal masing-masing pihak dan bahkan dapat ditanyakan trombo (arah keturunan) asal-usul untuk mengetahui tingkat kekerabatan tersebut. Jadi, tingkat kekerabatan seseorang dengan orang yang lainnya dapat ditentukan dengan Ertutur, sekalipun sudah jauh silsilah mereka berkaitan. Ertutur merupakan cara untuk mengetahui tingkat kekerabatan dengan yang lain. Ertutur ini menggunakan marga dari ayah dan ibu yang diturunkan ke anak. Marga dari ayah diturunkan ke anak laki-laki disebut marga, sedangkan untuk anak perempuan disebut beru. Marga dari ibu diturunkan ke anak laki-laki dan perempuan disebut bere-bere. Dari kedua kombinasi marga ayah dan ibu akan dapat ditentukan tingkat kekerabatan dengan marga yang lain. Tingkat kekerabatan yang lebih kompleks dapat digabungkan dari marga kakek dan nenek baik dari ayah maupun dari ibu.

Berkembangnya zaman modern yang tak terbendung lagi adat budaya. Ertutur sekarang ini mulai terkikis dan sudah seadanya saja. Hanya bertanya marga dan bere-bere saja, sedangkan untuk garis keturunan kempu, binuang, soler dan kampah sudah sangat jarang ditanyakan. Hal ini disebabkan 
generasi muda sudah tidak mengetahui apa saja garis keturunan yang melekat pada dirinya (Meliala \& Wardoyo, 2015). Banyak suku Karo yang tidak mengerti lagi cara ertutur. Orang tua yang seharusnya menjadi guru untuk mengajarkan cara ertutur kepada anak sudah tidak menganggap ertutur menjadi salah satu yang penting untuk diajarkan (Maha \& Surbakti, 2016). Betapa pentingnya peran ertutur dalam masyarakat Karo, setiap masyarakat adat Karo dapat membentuk lahirnya sistem istilah kekerabatan. Namun kebanyakan responden yang dijumpai penulis ialah mahasiswa Batak Karo yang sudah tidak mengetahui Soler, Binuang, dan Kampah-nya dikarenakan beberapa alasan yang diberikan misalnya karena dibesarkan di Kota, ketika bertemu dengan sesama Batak Karo perkenalan yang dilakukan hanya sampai Merga/Beru dan asal daerah, perkembangan zaman yang membuat adat ini tersampingkan dan banyak sekali alasan lain yang disampaikan kepada penulis (Ginting, Hambali, \& Haryono., 2019).

Budaya ertutur mulai terkikis akibat fenomena kemajuan zaman yang tidak dapat kita hindari. Di Kota Cimahi, budaya ertutur telah mulai ditinggalkan berikut hasil observasi yang dilakukan pada komunitas Persadaan Karo di Gereja Bethel Indonesia Sukawarna Cimahi. Dari jumlah empat puluh anggota dalam komunitas tersebut, hanya terdapat sebagian besar tidak memahami budaya ertutur. Untuk itu, penulis tertarik untuk melakukan penelitian mengenai Eksistensi Budaya Erturtur atau tradisi santun bertegur sapa Batak Karo di Kota Cimahi.

\section{Metode}

Penelitian dilakukan pada komunitas Persadaan Karo di Kota Cimahi sebagai sumber data yakni melalui tokoh agama, tokoh adat, serta keluarga Suku Batak Karo yang melakukan perkawinan campuran antar-etnis. Pendekatan yang dipilih dengan menggunakan pendekatan kualitatif. Penelitian kualitatif merupakan penelitian yang berlandaskan analisis sistematis yang digunakan untuk meneliti suatu kondisi objek yang alamiah, dimana peneliti merupakan kunci teknik pengumpulan data dilakukan dengan cara observasi, wawancara, dan dokumentasi serta analisis data bersifat induktif, memahami makna, mengonstruksi fenomena dan menemukan hipotesis (Sugiyono, 2017, hal. 57). Penelitian kualitatif berusaha memahami yang diberikan masalah penelitian atau topik dari perspektif populasi lokal yang dilibatkan. Kualitatif Penelitian ini sangat efektif dalam memperoleh informasi spesifik budaya tentang nilai-nilai, pendapat, perilaku, dan konteks sosial populasi tertentu (Readings, 2005).

Penelitian kualitatif merupakan penelitian yang berlandaskan analisis sistematis yang digunakan untuk meneliti suatu kondisi objek yang alamiah, dimana peneliti merupakan kunci teknik pengumpulan data dilakukan dengan cara observasi, wawancara, dan dokumentasi serta analisis data bersifat induktif, memahami makna, mengonstruksi fenomena dan menemukan hipotesis (Sugiyono, 2017, hal. 57). Penelitian kualitatif sebagai "bentuk penyelidikan empiris sistematis ke dalam artinya". Secara sistematis ia berarti "direncanakan, diperintahkan dan publik", mengikuti aturan disetujui oleh anggota komunitas penelitian kualitatif. Secara empiris, maksudnya bahwa jenis penyelidikan ini didasarkan pada dunia pengalaman (Goethals, Sorenson, \& MacGregor, 2004)

Melalui penelitian kualitatif kita dapat menjelajahi berbagai dimensi dunia sosial, termasuk tekstur dan menenun kehidupan sehari-hari, pemahaman, pengalaman dan imajinasi peserta penelitian kami, cara proses sosial, lembaga, wacana atau hubungan bekerja, dan pentingnya makna yang mereka menghasilkan (Mason, 2002). Dalam penelitian kualitatif instrumen utamanya adalah peneliti itu sendiri, namun selanjutnya fokus penelitian akan menjadi jelas, maka akan dibantu dengan melengkapi data lalu membandingkannya dengan data yang telah ditemukan dalam observasi maupun wawancara. Di dalam metode penelitian kualitatif, lazimnya data dikumpulkan dengan beberapa teknik pengumpulan data kualitatif, yaitu; wawancara, observasi, dan dokumentasi. Wawancara adalah teknik yang dirancang untuk memperoleh gambaran yang jelas tentang perspektif peserta tentang topik penelitian. Percakapan informal dan interaksi dengan anggota populasi penelitian juga merupakan komponen penting metode dan harus dicatat dalam catatan lapangan, se detail mungkin (Mason, 2002).

Analisis data peneliti menggunakan model interactive yang mengacu pada model Miles and Huberman (1984) yang meliputi reduksi data, penyajian data, dan kesimpulan (Miles \& Huberman, 1992). Dalam melakukan wawancara, peneliti membuat serta menyiapkan instrumen yang berisi mengenai pertanyaan-pertanyaan yang berkaitan eksistensi budaya ertutur etnis Batak Karo pada Komunitas Karo di kota Cimahi, Pengalaman, dan pengetahuan yang didapat dari sumber data yang 
Lili Halimah, Heni Heryani, Mada Kencana Barus. Eksistensi budaya erturtur atau tradisi santun bertegur sapa pada komunitas persadaan batak karo kota cimahi

merupakan masyarakat Batak Karo, serta tokoh adat yang mengetahui secara keseluruhan mengenai nilai budaya ertutur.

\section{Hasil dan Pembahasan}

Penelitian ini dilakukan pada komunitas Persadaan Karo yang berada di bawah naungan Gereja Bethel Indonesia Sukawarna. Gereja Bethel Indonesia Sukawarna berdiri pada tahun 1992 dan berkembang pesat hingga sekarang serta memiliki banyak cabang di setiap wilayah salah satunya di Kota Cimahi. Sejarah berdirinya komunitas ini dipelopori oleh Ibu Ruth Elfrida Purba pada Januari 2016, dengan visi-misi untuk membentuk suatu komunitas peribadatan suku Batak Karo. Misi dari komunitas ini ialah mengajak setiap jemaat dan acara yang terkait dengan suku Batak Karo. Dengan tujuan mempererat kembali tali persaudaraan jemaat suku Batak Karo di perantauan. Jumlah anggota komunitas ini berkisar 45 orang bahkan lebih, tetapi jumlah anggota yang aktif pada komunitas ini sekitar 25 orang lebih.

Pemaparan deskripsi hasil penelitian ini merupakan penyatuan dari sumber bukti yang berupa bagian-bagian dari pengumpulan data studi deskriptif. Proses wawancara dilakukan dengan menggunakan teknik snowball dan purposive terhadap tujuh narasumber yang ditemui pada Komunitas Persadaan Karo Cimahi. Narasumber yang berhasil diwawancarai secara intensif dan langsung oleh peneliti ialah Bapak Jasa. Barus selaku anggota komunitas Persadaan Karo, dilaksanakan pada 28 Febuari 2020; Ibu Nasren Natalina Colia selaku anggota komunitas Persadaan Paro, dilaksanakan pada 28 Febuari 2020; Ibu Ruth Elfrida Purba, selaku tokoh agama, dilaksanakan pada 1 Maret 2020; Bapak Pt.Em.Ir. Yusuf Sembiring Gurukinayan, M.A, selaku tokoh adat, dilaksanakan pada 2 Maret 2020; Saudara Hazel Barus, selaku anggota komunitas Persadaan Karo, pada 2 Maret 2020; Saudara Aditia Barus selaku anggota komunitas Persadaan Karo, pada 2 Maret 2020; Bapak Rembang Ginting, selaku tokoh adat, dilaksanakan pasa 2 Maret 2020.

\section{Eksitensi Budaya Ertutur Etnis Karo}

Eksistensi budaya ertutur etnis Karo bermula dari sistem kekerabatan, dimana setiap orang pada suku Batak Karo harus mengetahui hubungan kekerabatan mereka, walaupun telah merantau dan jauh dari kampung halamannya. Hubungan kekerabatan ini tercipta secara langsung ketika orang tua telah melahirkan anak-anaknya. Demikian halnya dengan masyarakat Batak Karo memiliki sistem kekerabatan yang diwariskan secara turun-temurun yang mencangkup bentuk ikatan kekeluargaan, sistem sosial, penyelesaian konflik, dan berbagai hal lainnya yang berkaitan dengan sistem kekerabatan (Sugiyarto, 2014).

Batak Karo menganut asas patrilineal, dimana garis keturunan menurut keturunan ayah. Sedangkan marga merupakan satu faktor yang penting untuk menentukan hubungan (pertalian) keluarga. Setiap laki-laki dan perempuan harus mempunyai marga dilaki (laki-laki) dan beru (perempuan). Di sisi lain hubungan kekeluargaan ini bermula dari ikatan yang berupa segitiga tungku atau pada masyarakat suku Batak Karo disebut sebagai sistem kekerabatan atau kelompok. Sistem kekerabatan tersebut dinamai dengan Sangkep Sitelu pada masyarakat suku Batak Toba disebu dengan Daliken Na Tolu (Sinuhaji, 2013, hal. 114). Kerabat (kade-kade) memiliki pengertian yang sangat luas, baik itu atas dasar hubungan darah maupun hubungan yang disebabkan oleh pernikahan, sehingga menimbulkan suatu hubungan kekerabatan baik antara pihak wanita maupun pria yang menikah (Rumapea \& Simanungkalit, 2015). Hubungan kekerabatan ini dikenal dengan istilah rakut sitelu, yang terdiri dari kalimbubu, senina, dan anak beru. Di dalam hubungan kekerabatan ini terdapat lima marga yang mengikat serta membentuk sebuah fondasi kukuh dan derajat kekerabatan pada suku Batak Karo yang dikenal dengan istilah tutur siwaluh.

Sejalan dengan pendapat dari hasil wawancara tersebut, Ricard dalam Sugiyarto (2017) mengemukakan pada masyarakat Batak Karo terdapat sistem kekerabatan yang diwariskan secara turun-temurun yang mencangkup bentuk ikatan kekeluargaan, sistem sosial, penyelesaian konflik dan berbagai hal lainnya yang berkaitan dengan sistem kekerabatan. Selanjutnya Yunus (1994, p. 3) mengemukakan bahwa pada kekerabatan suku Batak karo dikenal dengan istilah marga, kelompok marga tersebut terdiri dari lima marga induk yaitu, Karo-Karo, Ginting, Tarigan, Sembiring, dan Peranginangin. Kelima marga induk ini dikenal dengan marga silima, setiap marga silima memiliki cabang-cabang marga. Istilah marga merupakan sebutan untuk laki-laki, dan bru untuk perempuan. Selanjutnya, 
hubungan yang lebih luas dari perwujudan marga-marga pada masyarakat Karo adalah rakut sitelu (ikat yang tiga). Rakut sitelu ini mirip dengan pengertian dalihan natolu pada masyarakat Batak Toba. Rakut sitelu pada masyarakat Karo merupakan suatu istilah untuk menyatakan sistem kekerabatan yang saling mengikat antara sesama anggota masyarakat. Sistem tersebut didapat melalui kelahiran dan perkawinan. Adapun kelompok-kelompok tersebut adalah (a) kalimbubu, (b) anak beru, dan (c) senina. Ketiga bentuk ini disebut sangkep si telu. Istilah ini sama dengan Dalian na tolu pada masyarakat Batak Toba. Masyarakat Karo masing-masing sadar dan mengetahui poisisinya dalam sistem kekerabatan dalam adat-istiadat Karo dalam kaitannya antara merga silima dengan Sangkep si telu, sehingga dalam pelaksanaan sebuah upacara adat masing-masing individu (keluarga) telah mengetahui posisinya sebagai bagian dari upacara tersebut.

Kemudian pada suku Batak Karo Kalimbubu adalah tuan yang harus dilayani, sedangkan anak beru adalah pekerja atau pelayanan bagi Kalimbubu. Pada upacara pernikahan misalnya Kalimbubu adalah golongan saudara laki-laki atau ayah dari pihak istri yang mempunyai hajat dan Anak berunya adalah pihak yang ingin menikahi saudara perempuan dari yang punya hajat atau pesta adat. Pihak Sukut yang ingin melaksanakan suatu hajat atau upacara adat tertentu maka terlebih dahulu ia melakukan permusyawaratan yang dibantu oleh Senina. Senina tidak hanya berperan dalam membantu permusyawaratan tetapi juga sebagai mediator yang menghubungkan antara Kalimbubu dan Anak beru terkait hajatan atau upacara yang akan dilaksanakan. Oleh karena itu Senina haruslah orang terpilih berdasarkan kesepakatan keluarga bersama karena ia juga ikut bertanggung jawab atas kelangsungan acara, diutamakan seorang yang memiliki pertalian saudara dan memiliki kedekatan emosional sehingga ia memahami situasi dan kondisi keluarga Sukut atau dari keluarga yang memiliki hajat.

Selain itu Senina juga sebagai timbal balik terhadap Sukut, jika pada upacara kali ini menjadi Senina dalam hajatan rumah baru yang dilakukan oleh keluarga A, maka dalam upacara lain bisa pula diseninain oleh keluarga A pada upacara pernikahannya. Ketika Senina telah dipilih maka segala permusyawaratan terkait upacara atau hajatan harus menghadirkan Senina, keberadaan Senina sangat penting dalam permusyawaratan sekalipun pihak keluarga kandung telah hadir akan tetapi Senina yang paling berhak untuk berbicara mewakili Sukut. Anak beru yang bertugas sebagai pekerja atau pelayan dari Kalimbubu tidak diperkenankan melakukan dialog langsung dengan Sukut terkait acara, ia harus menyampaikannya lewat Senina selanjutnya diteruskan kepada Sukut. Misalnya pada upacara "mengket rumah mbaru" (memasuki rumah baru), maka Anak beru perlu menanyakan apa saja yang perlu dipersiapkan. Begitu juga pada pesta pernikahan Anak beru selalu berkomunikasi dan menanyakan keinginan kepada Kalimbubu melalui Senina. Misalnya, keluarga Sembiring menikahkan anak perempuannya, maka keluarga tidak diperkenankan untuk mengungkapkan langsung terkait biaya maharnya, ia berunding terlebih dahulu dengan keluarganya setelah ada kesepakatan di antara mereka barulah kemudian menyampaikan kepada senina.

Dalam suatu upacara adat tersebut masyarakat tidak memandang pangkat atau jabatan seseorang, Daliken Si Telu ini dipraktikkan secara terus menerus sejak zaman raja terdahulu, sekalipun ia merupakan bangsa raja jika posisinya dalam upacara adat adalah anak beru (pekerja dan pelayan) maka ia haruslah mengurus segala upacara adat, baik dalam hal memasak maupun dalam permusyawaratan untuk keberlangsungan acara adat tersebut. Dan itu berlaku juga saat ini baik Jenderal maupun Gubernur maka ia harus mengikuti hal yang sama.

Daliken Si Telu terus dilaksanakan melingkar secara turun temurun hingga saat ini setiap masyarakat Karo melakukannya berdasarkan ikatan kekeluargaan dan kesadaran bersama terhadap peraturan adat, dengan Daliken Si Telu maka setiap masyarakat Karo yang berasal dari kelompok keluarga dan marga yang berbeda akan bertemu dan berinteraksi secara aktif dalam upacara adat, sekalipun seseorang yang memiliki jabatan pemerintahan yang tinggi ketika ia dan kelompok keluarganya menempati posisi sebagai Anak beru dalam upacara adat maka ia tetap harus bekerja untuk melayani kalimbubunya sekalipun Kalimbubu seorang petani dan bukan pejabat negara. Karena Kalimbubu juga dianggap sebagai "Dibata Ni idah" (Tuhan yang kelihatan) sehingga harus dihormati dan dijunjung dalam batas kewajaran dan tidak berlebihan (Lubis, 2017, hal. 248).

Berdasarkan pendapat-pendapat di atas, dapat disimpulkan bahwa sistem hubungan kekerabatan pada suku Batak Karo, dimulai pada kelompok marga yang terdiri dari lima marga pokok, yang kemudian dapat membentuk kekerabatan yang disebut dengan istilah rakut sitelu. Batak Karo 
Lili Halimah, Heni Heryani, Mada Kencana Barus. Eksistensi budaya erturtur atau tradisi santun bertegur sapa pada komunitas persadaan batak karo kota cimahi

harus mengetahui sistem kekerabatan ini agar mengetahui posisinya baik dalam kehidupan seharihari maupun dalam upacara adat Karo.

\section{Pemahaman Komunitas Karo mengenai Tradisi Ertutur}

Pemahaman masyarakat suku Batak Karo di Kota Cimahi, khususnya anggota komunitas Persadaan Karo, pada Gereja Bethel Indonesia Sukawarna memang sudah mulai berkurang. Menurut ketua adat kota Cimahi ini sangat disayangkan karena akan menyulitkan saat ingin berkomunikasi antar masyarakat suku Batak Karo di Kota Cimahi.

Sejalan dengan pendapat Menurut Rogers \& Kincaid menyatakan bahwa komunikasi adalah suatu proses di mana dua orang atau lebih membentuk atau melakukan pertukaran informasi antara satu sama lain, yang pada gilirannya terjadi saling pengertian yang mendalam. Adapun tujuan dari komunikasi adalah membangun atau menciptakan pemahaman atau pengertian bersama. Saling memahami dan mengerti bukan berarti harus menyetujui, namun mungkin dengan komunikasi terjadi suatu perubahan sikap, pendapat, perilaku atau perubahan secara sosial (Rumono, 2014, hal. 4).

Menurut Berger, ilmu komunikasi adalah suatu pengamatan terhadap produksi, proses dan pengaruh dari sistem-sistem tanda dan lambang melalui pengembangan teori-teori yang dapat diuji dan digeneralisasikan dengan tujuan menjelaskan fenomena yang berkaitan dengan produksi, proses dan pengaruh dari sistem-sistem tanda dan lambang. Mereka mengkhususkan diri pada studi komunikasi antara manusia bahwa komunikasi adalah suatu transaksi, proses simbolik yang menghendaki orang-orang mengatur lingkungannya dengan membangun hubungan antara sesama manusia melalui pertukaran informasi untuk menguatkan sikap dan tingkah laku orang lain, serta berusaha mengubah sikap dan tingkah laku (Nurhina, 2013, hal. 179). Komunikasi adalah proses penyampaian suatu pesan oleh seseorang kepada orang lain untuk memberi tahu atau untuk mengubah sikap, pendapat, dan perilaku, baik langsung (komunikasi tatap muka) maupun tidak langsung atau komunikasi melalui media (Nurhad, 2017, hal. 91). Tujuan dari komunikasi adalah membangun atau menciptakan pemahaman atau pengertian bersama. Saling memahami dan mengerti bukan berarti harus menyetujui namun mungkin dengan komunikasi terjadi suatu perubahan sikap, pendapat, perilaku atau perubahan secara sosial (Rumono, 2014, hal. 4).

Harold (Oktavia, 2016, hal. 4) menyatakan, bahwa dalam proses komunikasi harus dapat menjawab pertanyaan" who say what, in wich channel to whom and with what effect". yaitu Who (siapa), berarti siapa yang menjadi komunikator. Say what (apa yang dikatakan), berarti isi pesan yang disampaikan harus diikuti atau dilaksanakan. In wich channel (saluran yang dipakai), saluran media yang dipakai dalam proses komunikasi adalah langsung atau tatap muka. To whom (kepada siapa), ini berarti sasaran atau komunikan. With what effect (efek yang timbul), akibat yang timbul setelah pesan itu disampaikan yaitu timbulnya suatu tindakan, dan terdapat tiga unsur penting dalam proses komunikasi yang dilakukan dalam komunikasi, yaitu, Sumber (source), di sini sumber atau komunikator adalah bagian pelayanan santunan. Pesan (massage), dapat berupa ucapan atau pesanpesan atau lambang-lambang. Sasaran (destination), adalah korban atau ahli waris korban (Klaimen).

Menurut aristoteles dalam (Wati, 2017, hal. 86) komunikasi dibangun oleh tiga unsur yaitu, orang yang berbicara. Materi pembicara yang dihasilkan, dan orang yang mendengarkannya. Orang yang berbicara disebut komunikator ataupun persuader yang merupakan sekelompok orang yang menyampaikan pesan dengan tujuan agar dapat mempengaruhi sikap, pendapat, maupun perilaku baik secara verbal maupun nonverbal. Pesan merupakan segala sesuatu yang dapat memberikan pengertian kepada penerima baik secara verbal maupun nonverbal, dan persuaded ialah orang maupun sekelompok orang yang menjadi tujuan penyampaian dan penyalur pesan-pesan oleh persuader.

Unsur-unsur lainnya yaitu strategi dalam komunikasi, pada faktor ini seorang komunikator dituntut untuk pandai dalam membuat rencana agar tujuan dari komunikasi dapat dicapai, kemudian unsur keterjangkauan yang dilihat dari dua segi baik segi teknologi maupun keterjangkauan daya beli masyarakat, segi teknologi menyangkut jenis teknologi apa yang harus digunakan melalui sebuah pertimbangan. Agar komunikasi berjalan efektif maka diperlukan perencanaan, adapun fokus perencanaan tersebut pada pesan maupun tujuan komunikasi, mengingat tujuan komunikasi untuk mengubah sikap, serta perilaku (Nurhadi \& Kurniawan, 2017, hal. 93).

Komunikasi yang terjadi di dalam kelompok adalah mekanisme fundamental di mana anggotanya berbagi rasa frustrasi dan perasaan puas. Komunikasi memberikan penyaluran perasaan 
bagi ekspresi emosional dan untuk memenuhi kebutuhan sosial. Informasi Individu dan kelompok memerlukan informasi untuk menyelesaikan sesuatu dalam organisasi (Ramadanty, 2014, hal. 3).

Kemudian menurut anggota komunitas Persadaan Karo dampak yang ditimbulkan jika tidak lagi diberikan pengertian dan pemahaman bagaimana kebudayaan adat karo itu kita khawatir suatu saat akan terjadi perkawinan yang seharusnya tidak bisa contohnya semarga tapi karna sudah perantauan sudah dihilangkan marganya jadi di kawin semarga mungkin dia pada saat keturunan keberapa dan itu akan mengakibatkan DNA nya lemah. Kemudian Tokoh adat serta ketua komunitas berpendapat bahwa dampak yang ditimbulkan bisa terjadinya pernikahan semarga, kemudian sudah tudai beradat lagi, karna itu hal yang harus kita tau dan tidak boleh dilupakan.

Pada intinya adalah setiap interaksi sosial dan hubungan antar dua individu atau lebih, di mana kelakuan individu yang satu akan mempengaruhi, mengubah, atau memperbaiki kelakuan individu yang lain ke arah yang lebih positif dan mendatangkan manfaat kepada perubahan dan peradaban manusia yang lebih baik dari masa ke masa (Budiarti, 2015, hal. 106). Pola perilaku manusia dalam suatu lingkungan adalah hasil dari proses interaksi manusia dengan lingkungannya yang melibatkan emosional individual dan sosial. Dalam menganalisa terhadap privasi dan kebutuhan sosianya tersebut diperlukan pendekatan melalui seting prilaku. Konsep ini mengacu pada seting perilaku yang terdiri dari 3 komponen, diantaranya ialah, fisik (desain), sosial (penggunaan), dan budaya (Hartono \& Pramitasari, 2018, hal. 87-89).

Sejalan dengan pendapat sejalan dengan Ospriani (2019, hal. 13), adat merupakan gagasan kebudayaan yang terdiri dari nilai-nilai budaya, norma, serta kebiasaan dan hukum adat yang telah lazim dilaksanakan di suatu daerah. Apabilah tidak dilaksanakan adat tersebut, maka akan menimbulkan sanksi yang tidak tertulis. Tata cara adat Batak pada umumnya, khusunya pada adat perkawinan merupakan tata cara yang bersumber dari nenek moyang serta leluhur. Kemudian Sukanto menjelaskan bahwa hukum adat merupakan sebagai kompleksiasi adat yang kebanyakan tidak ditulis maupun dikitabkan serta bersifat memaksa dan memiliki sangsi dan akibat hukumnya. Adapun wujud hukum adat terbagi menjadi tiga bagian yaitu hukum adat tidak tertulis yang merupakan bagian terbesar dari hukum adat, selanjutnya hukum adat yang tertulis merupakan sebagian kecil yang berisikan peraturan perundangan-uandangan yang dikeluarkan oleh raja-raja pada zamannya, kemudian hukum adat dalam wujud uraian-uraian hukum secara tertulis, lazimnya ini berbentuk hasil penelitian (Wignjodipoero, 1990, hal. 22).

\section{Faktor Penyebab Memudarnya Tradisi Ertutur}

Faktor penyebab memudarnya tradisi ertutur disebabkan karna faktor teknologi. Ketua adat kota Cimahi menjelaskan bahwa faktor lainnya ialah kurang pembelajaran serta pemberiaan pemahaman kepada generasi Muda pada umumnya. Kemudian upaya yang harus dilakukan agar tetap terjaga tradisi ertutur ini, tokoh adat meyampaikan bahwa akan membentuk sebuah komunitas dan akan memberikan pembelajaran mengenai erutur. Tokoh agama serta ketua komunitas Persadaan Karo juga mengunngkapkan bahwa lasannya membentuk komunitas ini agar tetap terjaganya tradisi suku Batak Karo di Kota Cimahi.

Sejalan dengan pendapat hasil wawancara tersebut Kelly dalam Veeger (1989, hal. 17) mendefinisikan bahwa kebudayaan ialah sesuatu yang berasal dari sejarah yang menjadi sebuah pedoman untuk tingkah laku manusia yang harus tetap dijaga, kebudayaan merupakan sebuah pengaplikasian manusia dalam sesuatu yang dapat diterima dan menjadi sebuah warisan. Kebudayaan dan masyarakat ibarat sekeping mata uang yang tiap sisinya saling berkaitan satu dengan yang lainnya. Kebudayaan tidak akan lahir tanpa adanya masyarakat (Triyanto, 2018, hal. 66). manusia memiliki budi serta akal pikiran sehingga manusia menjadi satu-satunya makluk hidup yang memilki kemampuan menciptakan hal-hal yang berguna (Bahar, 2017, hal. 4). Kebudayaan merupakan hasil intraksi kehidupan bersama, dimana manusia sebagai bagian dari masyarakat selalu mengalami sebuah perubahan, baik itu perubahan naik turun dalam kurun waktu tertentu. Dalam peroses perkembangan tersebut dibutuhkan kreatifitas serta tingkat peradapan masyarakat sebagai pemilik kemajuan peradapan tersebut (Teng, 2017, hal. 71)

Kemudian Garna dalam Wijakarno (2013, hal. 65) mengungkapkan bahwa tradisi ialah sebuah sistem dalam masyarakat tradisonal. Dalam menjaga lingkungan dan terdapat beberapa sistem kepercayaan, nilai-nilai budaya, serta cara berpikir. Mempertahankan ertutur pada suku Batak Karo adalah tugas bersama bagi masyarakat maupun pemerintah, dalam UUD 1945 pasal 32 ayat 1 , 
menyatakan bahwa Negara memajukan budaya nasional Indonesia ditengah peradaban dunia dengan menjamin kebebasan masyarakat dalam memelihara dan mengembangkan nilai-nilai budayanya.

\section{Simpulan}

Eksitensi budaya ertutur etnis Karo bermula dari sistem kekerabatan, dimana setiap orang pada suku Batak Karo harus mengetahui hubungan kekerabatan mereka, walaupun telah merantau dan jauh dari kampung halamannya. Hubungan kekerabatan ini tercipta secara langsung ketika orang tua telah melahirkan anak-anaknya. Hubungan kekerabatan ini dikenal dengan istilah rakut sitelu, yang terdiri dari kalimbubu, senina, dan anak beru. Di dalam hubungan kekerabaatn ini terdapat lima marga yang mengikat serta mebentuk sebuah fondasi kokoh dan derajat kekerabatan pada suku Batak Karo yang dikenal dengan istilah tutur siwaluh. Pemahaman tradisi ertutur tidak boleh dilupakan apalagi memudar, selain menjadi jati diri suku Batak Karo, tradisi ertutur juga merupakan hal serta kebiasaan yang dilakukan suku masyarakat Batak Karo pada saat melakukan intraksi dan komunikasi kepada sesama suku Batak Karo liannya, ini merupakan hal sederhana yang jika dilupakan maka akan berdampak pada, pernikahan semarga, lunturnya identitas, serta dianggap tidak lagi beradat. Faktor penyebab memudarnya tradisi ertutur disebabkan karna faktor teknologi, maka dari itu upaya yang harus dilakukan ialah dengan membentuk sebuah komunitas yang memberikan pembelajaran mengenai tradisi ertutur, agar tetap terjaganya tradisi ini diperantauan.

\section{Ucapan Terima Kasih}

Ucapan terima kasih kami haturkan kepada rekan-rekan penulis dan pimpinan Gereja Bethel Indonesia beserta Komunitas Persadaan Batak Karo Kota Cimahi, yang telah memfasilitasi kepertingan penelitian penulis.

\section{Referensi}

Bahar, M. (2017, Juni). Filsafat kebudayaan dan sastra (dalam prespektif sejarah). Jurnal Ilmu Budaya, $5(1), 2-14$.

Budiarti, M. (2015). Mengurai konsep dasar manusia sebagai individu melalui sosial yang dibangunnya. jurnal prosiding ks riset dan pkn, 4(1), 104-109.

Fadilah, N. (2012). Penerapan Sistem Selft Assesment pada Pajak Parkir dalam Upaya Mencapai Target Pajak Daerah. (p. 58). Bandung: Universitas Negeri Bandung (tidak untuk diterbitkan).

Ginting, K. A., Hambali, \& Haryono. (2019). Perubahan tradisi ertutur dalam etika kekerabatan pada mahasiswa suku batak karo di Kota Pekanbaru. JOM FKIP, 1-8.

Goethals, G., Sorenson, G., \& MacGregor, J. (2004). Encyclopedia of leadership. London, Thousand Oaks CA, New Delhi: SAGE Publications.

Hantono, D., \& Permatasari, D. (2018). Aspek perilaku manusia sebagai makluk individu dan sosial pada ruang publik. National of Academik journal Architectur, 5(2), 85-93.

Hartono, D., \& Pramitasari, D. (2018). Aspek prilaku manusia sebagai makhluk individu dan sosial pada ruang terbuka publik. jurnal national academic journal of architecture, 5(2), 85-93.

Herdiansyah, H. (2013). Wawancara, Observasi, dan Focus Groups (Sebagai Instrumen Pengaliahan Data Kualitatif). Jakarta: PT RajaGrafindo Persada.

Inah, E. N. (2015, Juni). Peranan komunikasi antar guru dan siswa. Jurnal Al-Ta'dib , 8(12), 176-188.

Kamaruzzaman. (2016, Oktober). Analisis keterampilan komunikasi interpersonal siswa. Jurnal Konseling, 2(2), 203-209. 
Kamus Besar Bahasa Indonesia Elektrik. (n.d.).

Karo, P. (2019, September 19). Data Komunitas Persadaan Karo. (Peneliti, Interviewer)

Koentjaraningrat. (2009). Ilmu Antropologi. Jakarta: PT Rineka Cipta.

Lubis, A. (2017, Desember). Budaya dan solidaritas sosial dalam kerukunan umat beragama. Jurnal Budaya, 11(2), 239-252.

Maha, S. H., \& Surbakti, Y. (2016, Mei). Membangun aplikasi ertutur dalam adat karo berbasis android. Jurnal Komunikasi, 30-34.

Mason, J. (2002). Qualitative researching . New Delhi: SAGE Publications London • Thousand Oaks.

Meliala, A. D., \& Wardoyo, R. (2015, Juni). Sistem hubungan kekerabatan ertutur dalam adat istiadat suku batak karo. Yogyakarta: Universitas Gadjah Mada.

Miles, M., \& Huberman. (1992). Analisis data kualitatif. (T. R. Rohidi, Trans.) Jakarta: UI Press.

Nasution, H. F. (2010). Instrumen Penelitian dan Urgensinya dalam Penelitian. Jurnal Penelitian, 1(2), 59-75.

Nugrahani, F. (2014). Metode Penelitian Kualitatif dalam penelitian Pendidikan Bahasa. Surakarta: Pilar Media Yogyakarta.

Nugrahani, F. (2014). Metode Penelitian Kualitatif dalam Penelitian Pendidikan Bahasa. Surakarta: Pilar Media Yogyakarta.

Nurhad, Z. F. (2017, Juli). Kajian tentang efektivitas pesan dalam komunikasi. Jurnal Komunikasi Hasil Pemikiran dan Penelitian, 5(1), 90-95.

Nurhadi, Z. F., \& Kurniawan, A. W. (2017). Kajian Tentang Efektivitas Pesan dalam Komunikasi. Jurnal Komunikasi, 3(1), 90-95.

Nurhina, E. (2013, Juli). Peran komunikasi dalam pendidikan. Jurnal Al-Tabib, 6(1), 176-188.

Oktavia, F. (2016). Upaya komunikasi interpersonal kepala desa dalam memediasi kepentingan PT. Bukit. Journal Ilmu Komunikas, 4(1), 1-15.

Ospiriani, R. (2019, Januari). Potensi konflik pernikahan tanpa adat Batak Toba. Jurnal JOM FSIP, $6(11), 2-15$.

PANOS, T. (2013). Roles of communication. London: panosnetwork.org/hello. Retrieved from panoslondon.panosnetwork.org: http://panoslondon.panosnetwork.org/our-work/whycommunication-matters/roles-of-communication/

Perangin-angin, B. B. (2015). Implementasi tradisi ertutur suku batak karo sebagai model komunikasi interpersonal mahasiswa perantauan di Yogyakarta. Yogyakarta: Universitas Atmajaya.

Prayogi, R., \& Danial, E. (2016). Nilai-Nilai Budaya Pada Suku Bonai sebagai Civic Culture di Kecamatan Bonai Derusalam Kabupaten Rokan Hulu Provinsi Riau. Jurnal Humanika, 23(1), 61-79. 
Lili Halimah, Heni Heryani, Mada Kencana Barus. Eksistensi budaya erturtur atau tradisi santun bertegur sapa pada komunitas persadaan batak karo kota cimahi

Ragawino, B. (2002). Pengantar dan Asas-Asas Hukum Adat Indonesia. Bandung: Universitas Padjadjaran.

Rahmat, P. S. (2009, Juni). Penelitian Kualitatif. Jurnal Equilibrum, 5(9), 1-8.

Ramadanty, S. (2014, Maret). Penggunaan komunikasi fatis dalam pengelolaan hubungan di tempat kerja. Jurnal Ilmu Komunikasi, 5(1), 1-118.

Readings, S. (2005). Qualitative Research Methods: A Data Collector's Field Guide Module 1 Qualitative Research Methods Overview 2005 FAMILY HEALTH INTERNATIONAL S Readings. USAID: FAMILY HEALTH INTERNATIONAL under the terms of Cooperative Agreement No. CCP-A-00-95-00022-02.

0-939704-986https://course.ccs.neu.edu/is4800sp12/resources/qualmethods.pdf .

Rohmat, E. (2018). Transformasi Nilai-Nilai Kearifan Lokal Upacara adat Huluwotan Sebagai Upaya Membangun Karakter Bangsa. (pp. 1-193). Cimahi: STKIP Pasundan.

Rumapea, M. E., \& Simanungkalit, D. A. (2015, Oktober). Dampak modernisasi terhadap upacara adat perkawinan masyarakat Batak Toba di Kota Medan. Jurnal Antropologi Sosial dan Budaya, $1(2), 167-174$.

Rumono, H. N. (2014). Hubungan intensitas komunikasi orangtua-anak. Jurnal Ilmu Komunikasi, 5(2), $1-10$.

Saini, N. (2019, November 26). Functions of Communication. Retrieved from www.quora.com: https://www.quora.com/What-are-the-functions-of-communication Nitesh Saini,

Sibero, T. M., \& Sibero, D. (2017, Juni). Tradisi merdang merdem kalak karo di Desa Juhar, Kecamatan Juhar, Kabupaten Karo, Sumatera Utara. Jurnal Sabda Jurnal Kajian Kebudayaan, 12(1), 91-100.

Sinuhaji, M. (2013). Pelestarian adat dalam upacara perkawinan masyarakat batak karo sebagai atrakstik wisata. Jurnal Geografi, 5, 114-122.

Society and Culture Hardware and Software of Our Social World Chapter 3. (2020, 5 27). Retrieved from sage.com: https://www.sagepub.com/sites/default/files/upm-binaries/40402_3.pdf

Sugiyarto. (2014). Menyimak (kembali) integrasi budaya di tanah Batak Toba. Jurnal Ilmiah Kajian Antropologi, 35.

Sugiyarto. (2017). Menyimak kembali integrasi budaya di tanah Batak. Endogami Jurnal Ilmiah Kajian Antropologi, 1(1), 34-41.

Sugiyono. (2017). Metode penelitian kualitatif. Bandung: Alfabeta Bandung.

Susilana, R. (2017). Penelitian Kualitatif. Jurnal Pennelitian, 02(1), 1-8.

Teng, M. B. (2017, Juni). Filsafat kebudayaan dan sastra (dalam prespektif sejarah). Jurnal Ilmu Budaya, 5(1), 69-75.

Triyanto. (2018, Januari). Pendekatan kebudayaan dalam penelitian pendidikan seni. Jurnal Imajinasi, 12(1), 65-76. 
Tubbs, L., \& Moss, S. (2005). Human communication: Prinsip-prinsip dasar. Bandung: PT Remaja Rosdakarya.

Veeger. (1989). Ilmu budaya dasar. Jakarta: PT Prenhallindo.

Wati, F. F. (2017, April 1). Kemampuan komunikasi persuasif pengelola museum Provinsi Sulewesi Tengah. Jurnal Online Kinesik, 4(1), 81-91.

Wignjodipoero, S. (1990). Pengantar dan asas-asas hukum adat. Jakarta: CV HAJI MASAGUNG.

Wijakarno, B. (2013, Oktober). Pewarisan nilai-nilai kearifan tradisonal dalam masyarakat adat. Jurnal Pendidikan Geografi, 13(2), 60-72.

Yulianti, D. (2017, Febuari). Kebudayaan Lokal versus Kebudayaan Global. Jurnal Sejarah, XI(1), 110 .

Yunus, A. (1994). Makna pemakaian Rebu dalam kehidupan kekerabatan orang Batak Karo. Jakarta: Dapertemen Pendidikan dan Kebudayaan (tidak untuk diperdagangkan). 